\title{
Technology of biologics for the protection of forests on the basis of mushroom Phlebiopsis gigantea with deep cultivation on alcohol stillage
}

\begin{abstract}
In the friction process of two materials and in the presence of some proper lubricants, Background: In the Republic of Belarus as well as in the world acute problem of protecting forests from diseases and pests. The damage caused by root rot is essential, therefore, the problem of forest protection is an urgent task. The biologics has the greatest prospects in according with traditional methods of struggle. Deep method of cultivation of a mushroom Phlebiopsis gigantea with use of nutrient mediums on the basis of ethanol stillage and its components (fugat) is researched. Feasibility of use stillage as raw materials in production of a biological product for the wood protection against root decay is shown. The effect of different additives (sawdust, fodder yeast) on the accumulation of reactive biological product-oidy has been studed It was determined that the deep cultivation using sawdust of the highest accumulation oidy $\left(1.510^{6} \mathrm{units} / \mathrm{ml}\right)$. It was also found that the stillage is the best breeding ground for fungus biomass accumulation $(7.99 .8 \mathrm{~g} / \mathrm{l})$ versus fugat $(6.06 .6 \mathrm{~g} / \mathrm{l})$. On the basis of research work the technological scheme for production of a biological product were developed.
\end{abstract}

Keywords: forest loss by root rots, biologics for the forests protection, Phlebiopsis gigantea, deep cultivation, oidii, alcohol stillage
Volume 3 Issue 3 - 2018

\author{
Ilya Kuznetsov, Nickolay Ruchai \\ Department of Biotechnology and Bioecology, Belorussian State \\ Technological University, Belarus
}

\section{Correspondence: llya Kuznetsov, Department of} Biotechnology and Bioecology, Belorussian State Technological University, zip cod 220006, Sverdlova 13a str., Minsk, Belarus, Tel +37529179 598I, Email i.n.kuznetsov@gmail.com

Received: July 02, 2018 | Published: August 10, 2018

\section{Introduction}

Important in nature and human life are forests. Forests, including those planted by man, occupy an area of about 40 million $\mathrm{km}^{2}$, or about $1 / 3$ of the land surface and affect all components of the biosphere. Forests perform a number of important natural functions: purify the air, create habitats for animals, protect the soil from erosion, delay precipitation (reduce surface runoff), create a favorable microclimate for agricultural plants, anchor sands, and prevent contamination of water bodies. ${ }^{1-3}$ All forests are subject to protection from fires, illegal logging, violations of the established procedure for forest use and other actions that damage the forest, as well as protection from harmful insects and diseases. ${ }^{4}$ Damage and defeat of forests by harmful insects and diseases cause great damage to the national economy of the country in the form of losses of current growth of wood, drying and degradation of stands, reduction of their nature protection, water protection and agro forestry functions. Forest protection is an obligatory component of forest protection, the purpose of which is to maintain, preserve and enhance the resource potential and biological diversity of forests, which are not only domestic but also world wealth. ${ }^{5}$ The damage to the forestry of the whole world by root rot is enormous. A considerable amount of research work has been devoted to the problem of root rot, which enabled us to obtain detailed information on the biology, prevalence and harmfulness of pathogens. In our country and abroad, the problem of developing effective methods and means of protecting forest plantations from root rot is acute. ${ }^{6}$ There are several ways to control the root sponge, such as treatment with chemical agents, sanitary felling of forests and biological methods. The most effective and environmentally friendly is the use of microbials. ${ }^{6-8}$
Traditionally, biological products for protecting forests from root rot in the world practice are produced by periodic surface cultivation. At the same time, the perspective has deep cultivation with the use of cheap waste products for food production, for example post-alcohol bard. Thousands of victims of medical errors exist in the clinical realm. ${ }^{4,5}$ Most of these types of errors have occurred in the past, meaning the same modality is occurring again and again, harming our beloved patients and certainly discouraging healthcare professionals. Yet the flipside of the coin is that we can prevent the repeatedly occurring errors only if we have information on the mechanism - namely, how the errors occur. To address this issue, many error reporting systems have been developed and are currently in operation. ${ }^{4,5}$ Each of these systems has various fields of interest; some collect reports from all medical errors whereas others focus on a specific part of medical care, such as surgical events or intensive care units. The object of the study was the Phlebiopsis gigantea mushroom strain from the Museum of Microorganism Cultures of the Department of Forest Protection and Timber Studies of the Belarusian State Technological University.

\section{Methods}

In the experiments, the growth of the fungus on liquid nutrient media (mash) with various additives was studied. Liquid media were prepared on the basis of alcohol stillage by the ethanol production from rye obtained by dividing the stillage with Berezinsky distillery (Berezino, Belarus) by centrifuging at $5000 \mathrm{~g}$ for $10 \mathrm{~min}$. To enrich the nutrient media used dry fodder yeast, molasses and sawdust-stimulants of the formation of oidium. ${ }^{7}$ The following media and reagents were used: aglum, $\mathrm{NaOH} 1 \mathrm{M}, \mathrm{H}_{2} \mathrm{SO}_{4} 1 \mathrm{M}$. The initial inoculum was obtained by increasing the biomass of the fungus in Petri dishes on aglum at a 
temperature of $22-25^{\circ} \mathrm{C}$. On the end of 9-10 d all the surface of Petri dish covered by fungus micellium. Then mycelium was disintegrated and large number of vegetative oidium had recieved.

Deep cultivation of the fungus was carried out in flasks with a volume of $250 \mathrm{ml}(200 \mathrm{ml}$ of liquid nutrient medium) with mechanical stirring by a magnetic stirrer. The investigated liquid nutrient media were inoculated with the culture according to the method of agar blocks cut from the surface of the agar medium. For the enrichment of liquid nutrient media, dry fodder yeast, molasses and sawdust (stimulants of oidium formation) were used. The $\mathrm{pH}$ of the starting media is 4.24 .5 , the cultivation temperature is $22-25^{\circ} \mathrm{C}$ and the duration is up to 12 days. Determination of the amount of dry mass of the mycelium of the fungus. The concentration of dry biomass of the fungus in the culture liquid was determined by the weight method with separation of the mycelium by filtration, followed by drying to constant weight at $105^{\circ} \mathrm{C}$. The amount of oid in the culture liquid was counted in the Goryaev chamber. ${ }^{7}$

\section{Results}

In the world practice, preparations of wood-destroying fungi to protect coniferous plantations from the root sponge are mainly obtained by surface cultivation of fungi on solid media, which ensure the formation of a large number of viable spores, the oidies shown in Figure 1, in the surface layer of the mycelium. 1. Oids retain their activity under certain conditions for 5-6 months. The production of such preparations is hampered by a complex composition of nutrient media containing sawdust, potato flour, peptone, molasses and other components, as well as labor-intensive production and low productivity of plant plants. A more productive and much less laborious is the deep method of cultivation of fungi. However, in this case, it is necessary to select the composition of the nutrient medium, which ensures a sufficiently high level of oidium formation. Experiments on deep cultivation of Phlebiopsis gigantea fungus in flasks with a liquid nutrient medium on the basis of post-alcohol bard showed that bard is a full nutrient medium providing a high level of accumulation of the fungal biomass of $6.09 .8 \mathrm{~g} / \mathrm{l}$ medium with a duration of 12 days. From Table 1 shows that sawdust is the most preferred stimulator of oid growth.

Table 1 Deep cultivation of Phlebiopsis gigantea in shaking flasks with mechanical stirring on liquid nutrient media

\begin{tabular}{|c|c|c|}
\hline The nutrient medium & $\begin{array}{l}\text { The amount of } \\
\text { dry biomass of the } \\
\text { fungus, } g / l\end{array}$ & $\begin{array}{l}\text { Oidium } \\
\text { amount, } \mathrm{mln} / \\
\mathrm{ml}\end{array}$ \\
\hline \multicolumn{3}{|l|}{ Cultivation period $12 \mathrm{~d}$} \\
\hline stillage $+0,5 \%$ fodder yeasts & 8,2 & 1,16 \\
\hline $\begin{array}{l}\text { Stillage fugate }+0,5 \% \text { fodder } \\
\text { yeasts }\end{array}$ & 6,6 & $\mathrm{I}, 38$ \\
\hline Stillage $+5 \%$ sawdust & 9,8 & $\mathrm{I}, 50$ \\
\hline Stillage fugate $+5 \%$ sawdust & 6,2 & $\mathrm{I}, 48$ \\
\hline Stillage $+2 \%$ molasses & 7,9 & 0,84 \\
\hline Stillage fugate $+2 \%$ molasses & 6,0 & 1,12 \\
\hline
\end{tabular}

A repeated experiment in a laboratory fermenter using as a liquid nutrient medium a post-alcoholic fugate with the addition of sawdust showed the results presented in Table 1, Table 2. Thus, the results of the previous research work ${ }^{7}$ ndicate that ethanol production wastesthe post-alcohol bard and its fugate are a favorable and inexpensive nutrient medium for the accumulation of the biomass of the wooddestroying fungus Phlebiopsis gigantea, which makes this raw material promising for the production of a biopreparation preventing propagation in the forest stands of the root sponges. Based on the results of studies performed at the Department of Biotechnology and Bioecology of the Belarusian State Technical University, a technological scheme has been developed (Figure 2) for obtaining a biological preparation for forest protection by cultivating the Phlebiopsis gigantea.

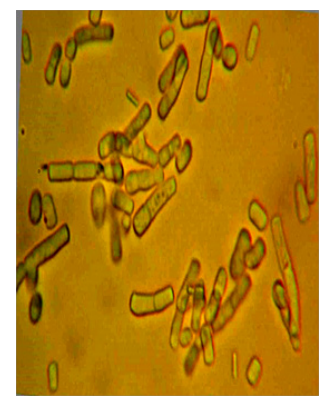

Figure I Oidium Phlebiopsis gigantean.

Table 2 Deep cultivation of Phlebiopsis gigantea in a laboratory fermentator

\begin{tabular}{|c|c|c|c|c|}
\hline Days of cultivation & 3 & 5 & 8 & 10 \\
\hline $\begin{array}{l}\text { The amount of dry biomass } \\
\text { of the fungus, г/л }\end{array}$ & 2,7 & 4,0 & 5,1 & 5,9 \\
\hline $\begin{array}{l}\text { Oidium Amount, mln./ ml } \\
\text { of medium }\end{array}$ & 0,23 & 0,51 & 0,70 & 1,22 \\
\hline
\end{tabular}

As shown in Table 1, the fugate of bard, in comparison with the natural after-alcohol bard, provides a lower level of accumulation of the fungus's biomass $(6.0-6.6 \mathrm{~g} / \mathrm{l})$, but the amount of oid in the cultured liquid $(1.12-1.5 \mathrm{mil} . / \mathrm{ml})$. The designed technology provides for the use as the main component of the nutrient medium for the cultivation of the fungus alcohol stillage, which is an onerous waste in the production of ethanol from grain raw materials. Research introduce that the nutrient medium based on the fugate stillage provides a high level of accumulation of the biomass of the fungus, and the presence in the medium of $5 \%$ of sawdust stimulates an increase in the proportion of oidium in the culture liquid.

When cultivating the fungus, it is necessary to observe aseptic conditions, which is taken into account in the technological scheme (hermetic fermenter, sterilization of nutrient medium, technological equipment, communications and air). The finished product in a paste-like form has a low cost and is comfortable to prepare working suspensions of a biological product when it is used. To improve the consumer properties of the biopreparation, the product is enriched with stabilizing additives, which increase the cell viability, improve adhesion of the preparation to the surface of the wood and ensure the stability of the aqueous suspension.

The technological scheme (Figure 2) includes the following main stages: accumulation of seed in Petri dishes on agar medium, increasing the amount of fungal biomass by cultivation in shaking flasks in a liquid medium, manufacturing fermentation and obtaining a product pasty-like product. Technoligical process starting from accumulation of inoculum is made by inoculating oidium of Phlebiopsis gigantea mushroom on agar medium (wort agar) with observance of aseptic rules. Petri dishes with a seeded medium are incubated for 10 days at 
a temperature of $25 \pm 2^{\circ} \mathrm{C}$. Oidium is washed off from the surface of the agar medium with sterile water and the suspension is transferred to a rocking flask containing a grain jug fugate and sawdust. Cultivation is carried out for 5 to 6 days. at temperature of $25 \pm 2^{\circ} \mathrm{C}$ with mechanical stirring of the medium by a magnetic stirrer. The seed medium from the shaker flasks is seeded with the production medium in the fermenter (2) equipped with a stirring device. A technological scheme for obtaining a biological preparation for forest protection by deep cultivation of the fungus Phlebiopsis gigantea is shown in Figure 2.

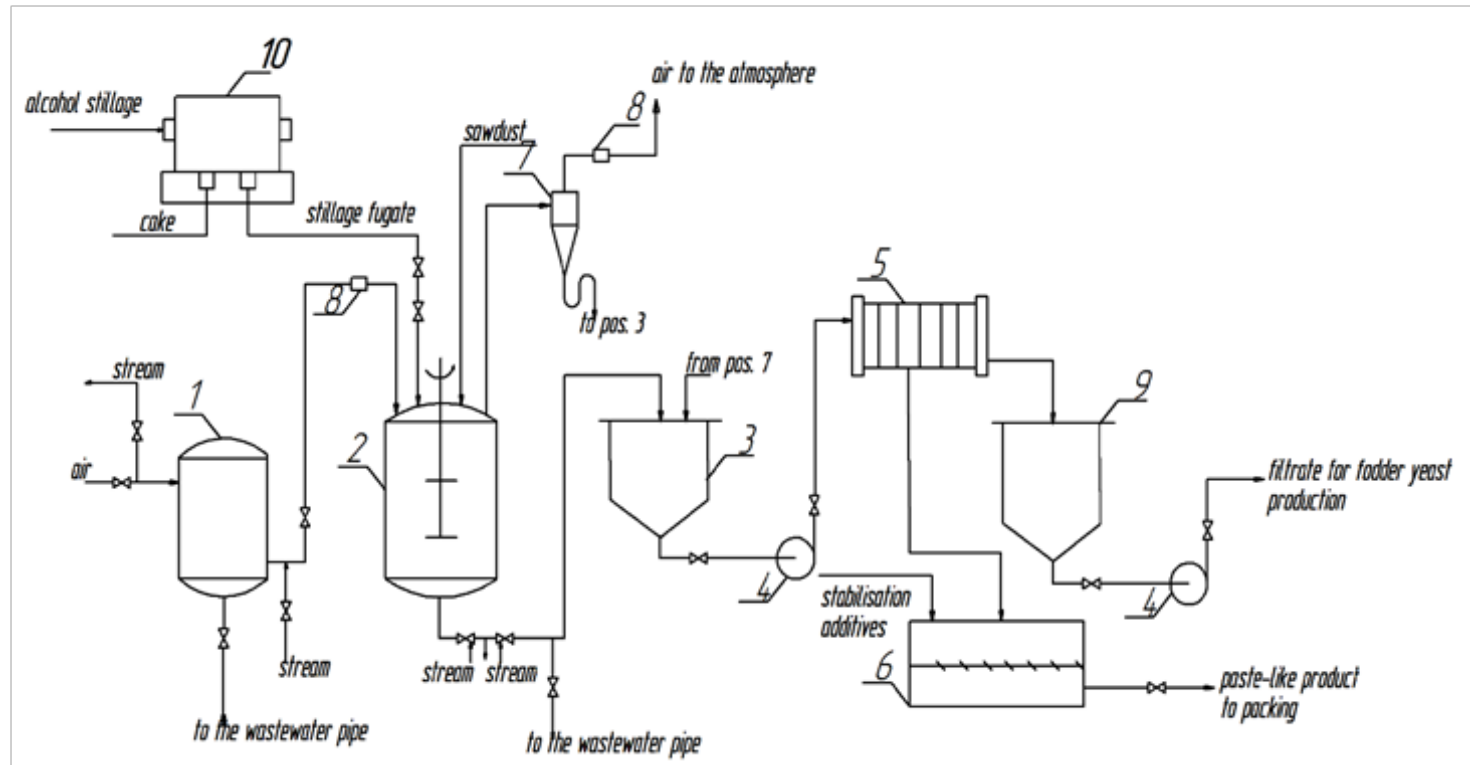

Figure 2 Technological scheme for obtaining biological products for forest protection by deep cultivation of Phlebiopsis gigantea: $I$ - the head filter; 2 - fermenter; 3 - capacity for cultural medium; 4 - the pump; 5 - frame filter press; 6 - mixer; 7- cyclone; 8 - individual filter; 9 - capacity for filtered cultural medium; 10 - decanter centrifuge.

The nutrient medium of the production fermenter is a fugate of stillage containing $5 \%$ of sawdust. Fermentation is carried out under aseptic conditions at a temperature $(25 \pm 2)^{\circ} \mathrm{C}$ and the $\mathrm{pH}$ of the initial medium is 4.8-5.5.

Sterile air is obtained by cleaning the head filter (1) and the individual filter (8). The duration of cultivation is 10 days with achievement of a biomass concentration of the fungus of $1.5-2 \%$ with a share of oidium $1.0-2.0 \mathrm{mln} / \mathrm{ml}$. The exhaust air from the fermenter before discharge into the atmosphere is purified in the system "cyclone+ strainer".

The culture liquid from the fermenter enters the collector (3), from which it is transferred to the frame filter press (5) by the pump (4) to separate the biomass of the fungus. The filtrate of the culture liquid is collected in a collection (9) and used as a nutrient medium component in the production of fodder yeast. To obtain the finished product, it is necessary to add a number of additives that increase the shelf life of the product, which protects the biomass from ultraviolet rays, as well as the effective distribution of oid in the water and the improvement of biomass fixation on the surfaces to be treated..$^{9-15}$

\section{Conclusion}

A deep method of cultivation of the Phlebiopsis gigantea fungus on ethanol waste (stillage, fugate stillage) for the production of a biological preparation for forest protection was studied. Deep cultivation was carried out with the addition of various growth stimulants of oidium: molasses, fodder yeast, and sawdust. It was determined that with deep cultivation, the highest level of accumulation of oidium $\left(1.5 \cdot 10^{6}\right)$ was achieved using wood sawdust. Established that stillage is the best nutrient medium for accumulation of fungal biomass (7.9-9.8 g/1), in comparison with a fugate (6.0$6.6 \mathrm{~g} / \mathrm{l})$. Based on the conducted studies, a technological scheme was proposed for obtaining a biological preparation by deep cultivation of the fungus Phlebiopsis gigantea.

\section{Acknowledgements}

None.

\section{Conflict of interest}

The author declares o conflict of interest.

\section{References}

1. Pavlov IN. Technogennie I bioticheskie mehanizmi destrukcii korennih lesov juga Sibiri I ih vostanovlenie: avtoreferat of $\mathrm{PhD}$ work: 06.03.03; 03.00.16. M., 2007. p. 44.

2. Strahov VV. Globalixacija lesnogo hoziajstva/V. V.Strahov, A.I.Pisarenko, VA. Borisov. - Moskow: VNIIClesoresurs, 2001. - 400 pp.

3. Sostojanie lesov mira. FAO UNDP. 2011. p.164.

4. Semenkova IG, Sokolova ES. Fitopatologiya [in English] Moskow, Izdatelskiy tsentr. Akademiya. 2003. p. 480.

5. Timchenko GA, Avramenko ID, Prokomenko NI. Spravochnik po zashchite lesa ot vrediteley i bolezney [на англ.] Kiev Urozhay. 1988; p. 224.

6. Negrutskiy SF. Kornevaya gubka. [in English] Moskow, Lesnaya promyshlennost, 1986. p. 186.

7. Kuznetsov IN, Ruchay NS. Issledovanie rosta griba Phlebiopsis gigantea na otkhodakh proizvodstva etanola dlya polucheniya 
biopreparata zashchity lesa Sbornik materialov II Mezhdunarodnoy nauchno-prakticheskoy konferentsii «Veterinarnaya meditsina na put innovatsionnogo razvitiya» posvyashchennaya 15-letiyu obrazovaniya fakul'teta veterinarnoy meditsiny. 95-100.

8. Волченкова ГА. Звягинцев В.Б. Развитие биологических методов ограничения вредоносности корневой губки/Проблемы лесоведения и лесоводства : Сборник научных трудов ИЛ НАН Беларуси. Вып. 71.-Гомель: ИЛ НАН Беларуси. 2011;445-455.

9. Korhnen K. Fungi belonginc to the Genera Heterobasidion and Armilaria in Eurasia/K.Korhonen//Gribnie soobschestva lesnih ecosystem: materialy koordinatsionnih issledovaniy/V.G. Storojenko, V.I. Krutova - Moskow - Petrozavodsk, 2004. p. 310.

10. Heterobasidion annosum: biology, ecology, impact and control/S. Woodward [et al.]. Cambrige: University Press. 1998. p. 589.

11. Vasiliauskas A. Rekomendacijos šakninès pinties plitimui apriboti spygliuočiu medynuose ir miško veisimui žemès. Vilnius: Miškų departamentas. 2008. p.16.

12. Metodichwskie rekomendacii po primeneniju biologichskih sredstv zaschiti rastenij I mikrobiologicheskih udibrenij $\mathrm{v}$ rastenievodstve. Volgograd. 2013. p.128

13. http://www.bellesozaschita.by/

14. Волченкова ГА, Звягинцев ВБ, Савицкий АВ. Скрининг штаммов Phlebiopsis gigantea (Fr.) Jülich по приживаемости на пнях соснь после рубок ухода/Труды БГТУ-2013;1:219-222.

15. Волченкова ГА, Звягинцев ВБ. Отбор штамов Phlebiopsis gigantea для разработки биологического препарата, ограничивающего вредоносность корневой губки/Проблемы микологии и фитопатологии в XXI веке : мат. Междунар. научной конф. СПб. $2013 ; 119-121$ 